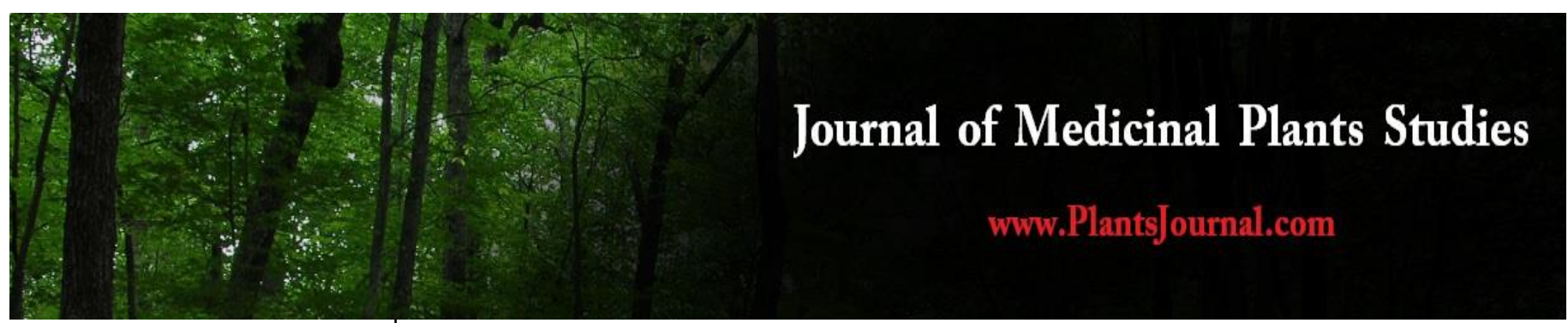

ISSN (E): 2320-3862

ISSN (P): 2394-0530

NAAS Rating: 3.53

www.plantsjournal.com

JMPS 2021; 9(3): 141-155

(C) 2021 JMPS

Received: 19-03-2021

Accepted: 22-04-2021

Janmejay Pant

University Institute of Pharma

Sciences, Chandigarh University,

Mohali, Punjab, India

Ripudaman M Singh

University Institute of Pharma

Sciences, Chandigarh University,

Mohali, Punjab, India

Harneet Marwah

University Institute of Pharma

Sciences, Chandigarh University,

Mohali, Punjab, India
Corresponding Author:

Ripudaman M Singh

University Institute of Pharma

Sciences, Chandigarh University,

Mohali, Punjab, India

\section{Methods employed in quality control in ayurveda}

\author{
Janmejay Pant, Ripudaman M Singh and Harneet Marwah
}

DOI: https://doi.org/10.22271/plants.2021.v9.i3b.1281

\section{Abstract}

Asava-arishta, the medicinal characteristics of Ayurvedic classical dosage forms, liquid dosage forms based on self-generated alcohol with faster absorption, long shelf life and increased market conformity have led to a continuous rise in demand. New fermentation methods and packaging innovations tend to have been embraced by many Ayurvedic processing units. The importance of standardisation of such goods is underlined by these advances in manufacturing, distribution and storage. Therefore, it is of concern to examine the latest manufacturing situation and the standardisation of the dosage type as regards the procedure and the consistency and effectiveness of the finished product. In addition to the effort to include criteria of consistency and standardisation, the study includes an overview and deliberates on the importance of improvements made to the conventional preparation processes, ingredients and material used in the process and the potential impact on its efficacy.

Keywords: Asava-arishta, ayurveda, medicinal plant, quality control, standardisation

\section{Introduction}

Ayurvedic medicine system is advantageous to humanity, but there is still a lack of appropriate standardisation techniques for determining its consistency, quantity and effectiveness. In order to standardise and admeasure the main biomarker molecules through nuclear drug and formulations from poly-herbal, chromatographic methods are precise, as per WHO guidelines. The oldest prevalent system for dealing with disease is utilise of therapeutic plants in treating diseases. In ancient civilised countries such as Africa, China, Egypt, India and South America etc., $80 \%$ of the community relies on herbal treatment to treat countless fatal Illnesses such as AIDS, cancer, malaria, etc. A variety of local programmes announce the presence of about 800 medicinal plants, such as Ayurveda, Siddha, \& Unani medicines [1]. Production of conventional drugs has contributed to a reduction in utilise of Ayurvedic plants products in the twentieth century. In recent years, thanks to thorough studies on pharmacological impact on human health care, herbal remedies have steadily acquired significant acceptance and renown. While much focus and study has been attempted in recent years, there is still inadequate knowledge on herbal medicine phytochemistry and metabolomics, which has developed a major challenge in standardisation methods ${ }^{[2]}$. The proper protection and effectiveness standards for human quality of life should be practised by herbal remedies or phytomedicine [3]. Therefore, the quality management and standardisation protocols of herbal drugs have required a system.

There are two types of Ayurveda formulations: developed only from 1 herb and poly-herbal formulations processed from the mixture of several herbs ${ }^{[4]}$. The highest quality evaluation of herbal ingredients, as described in the literature, relies on observational studies. Physicochemical, microscopic and macroscopic research ${ }^{[5]}$. For the authentication of herbal/polyherbal Ayurvedic formulations, standardisation protocols using non-conventional analytical practises are therefore required. Preliminary analysis of biologically susceptible marker agent is currently getting much successful in herbal medication verification and thus helps to decrease adulteration. ${ }^{[6,7]}$

\section{Quality evaluation of Ayurvedic drug}

The main requirements for their acceptability in western medicine are quality management and standardisation of raw materials and Ayurvedic medicines. These guarantee the right of the user to get basic, healthy, potent and effective prescription. Bioactive extracts can be standardised using chromatographic and spectroscopic techniques according to the active theory or main compound(s). 
Having a safe Ayurvedic commodity with full shelf-life is the next crucial step. ${ }^{[8]}$ However, there are some significant things that need to be concentrated in human healthcare for the growth and adoption of Ayurveda globally for medicines. According to Ayurveda, plant content collection is a very significant part of the medicinal plant's consistency since there are many variables that need to be considered before collection. In order to attain the best qualities of medicine, the particular location, part, process and time for selection is more important. When gathering plant products, the significant factors influencing the nature of medicines like Desha, Guna, Kala, Karma \& Disha, nav-purana avastha, Pakva-apakva avastha, Prayojyanga, have to be addressed ${ }^{[9]}$. With properly performed harvesting techniques, the phytoconstituents of medicinal plants are usable, so extract the herbs is required to achieve optimal benefits and good therapeutic results ${ }^{[10]}$.

In Ayurveda, there are four plant collection methods that have been identified as Bhumi pariksha (land deciding), Sangrahaniya dravyas (drug deciding), Sangrahaniya Vidhi (cultivation method) \& Sangrahaniya Kalaa (period for storage). Significance of Ritu (seasons) in Ayurvedic herb production and fruiting is defined by Charaka. The basic feature should be plants (Rasa in abundance, i.e., Veerya, and Gandha in appropriate periods for its obtaining). Charaka also emphasises the influence of moon, planets, stars, sun, wind \& heat on opioid embodiments of Prabhava, Rasa, Veerya and Vipaka.

According to advance science, period of collection often influences efficacy of drugs by shifts in many variables.
These variables include climate, temperature, rainfall, daylight period, altitude, cultivation practises, lunar cycle influence, wild area collection, soil quality and aggregation, processing \& keeping methods that play a major role on secondary metabolites ${ }^{[9]}$. The appropriate selection approach seeks to achieve the highest purity of the true medication that can increase the consistency and therapeutic effectiveness of Ayurvedic medicines.

\section{Quality control of Ayurvedic medicine}

Ayurvedic medicine quality management involves understanding what is in the plant's chemical materials, what occurs while manufacturing, chemical inspection \& biological assessment is being performed before final material arrives the user ${ }^{[11]}$. With regard to the contamination and adulteration of conventional drugs, significant questions are being raised around the world. Fertilisers, fungicides, biocides and radioactives may be pollutants. Moreover, inexpensive tree products with identical Pharmaceutical compound or biochemical results may contain adulterants ${ }^{[12]}$. In pharmaceutical formulation, for empirical and batch to batch heterogeneity, all sufficient knowledge related to horticulture related products should be considered with reasonable deliberation. It is important to assess the description, analytical specification of Ayurvedic formulation on the basis of the various specifications as described in Ayurvedic Pharmacopoeia ${ }^{[13]}$. In Table 1 , the various important criteria for the quality assessment of Ayurvedic drugs are mentioned. Their evaluation in logical terms and reporting can be depends on different advanced techniques.

Table 1: Quality control specifications of Ayurvedic Medicines

\begin{tabular}{|c|c|}
\hline Ayurvedic Characteristic & Advanced Characteristic \\
\hline Bahya/rasayanika parikasha & $\begin{array}{l}\text { Heavy/toxic metal analysis } \\
\text { Lead, cadmium, mercury, arsenic } \\
\end{array}$ \\
\hline \multirow{6}{*}{ Darshana pareeksha } & Color \\
\hline & Description \\
\hline & Disintegration time \\
\hline & Friability (If tablet) \\
\hline & Hardness \\
\hline & TLC/HPLC/HPTLC-Profile with marker \\
\hline Darshana and Sparshana pareeksha & Particle size, bulk density, tap density \\
\hline Desha pariksha & $\begin{array}{l}\text { Pesticide residue analysis } \\
\text { - } \quad \text { Organo-chlorine pesticide } \\
\text { - } \quad \text { Organo-posphorous pesticide } \\
\text { - Synthetic pyrethroids }\end{array}$ \\
\hline Ghrana pareeksha & Odour \\
\hline Krimi,/desha pariksha & $\begin{array}{l}\text { Microbial analysis } \\
\text { - Total viable aerobic count, } \\
\text { - Total enterobacteriaeceae, } \\
\text { - Total fungal count }\end{array}$ \\
\hline Krimi,/desha pariksha, Panchgyanendriya pariksha & $\begin{array}{ll}\text { Test for specific pathogen } \\
-\quad \text { E coli } \\
\text { - } & \text { Salmonella sp. } \\
\text { - } & \text { S. aureus } \\
\text { - } & \text { Pseudomonas aeruginosa } \\
\end{array}$ \\
\hline Mana pariksha & $\begin{array}{l}\text { Tablets/Capsules } \\
\text { - Uniformity of weight/content }\end{array}$ \\
\hline Prabhava karakas & $\begin{array}{l}\text { Test for Aflotoxins } \\
-\quad(B 1+B 2+\mathrm{G} 1+\mathrm{G} 2)\end{array}$ \\
\hline Prabhava sheela matra & Optimum effective dose \\
\hline Sandhana karakas & Binders \\
\hline Saviryata avadhi & Shelf life \\
\hline Prakshipta dravyas & Preservative \\
\hline Rasana pareeksha & Taste \\
\hline Virya & Active compound \\
\hline Vishakta matra & Lethal dose \\
\hline
\end{tabular}




\section{Quality measurement approaches}

Herbs are standardised depending on existence, where active markers are not yet identified, of an established active component or specific markers. But depending on the signature fingerprints, these may assist in determining the consistency of the commodity. Plants contain multiple active substances in the uniform extracts at certain ratios. It is important to keep this fix proportional, from 1 planning to other, within narrow limits. The particular methods of processing used for manufacture of herbal items convert Ayurvedic additives into perplexed compositions, those in some cases make it more difficult to isolate, classify and estimate chemical components. In addition, herbs are considered to have many components and the absolute molecule capable for therapeutic responsible is uncertain in several instances ${ }^{[14]}$.

For all factors relating to the consistency of Ayurvedic medicine, standardisation methods should be taken into account, including proper sample recognition, organoleptic analysis, volatile substance, pharmacognostic analysis, quantitative analysis, microbial load, xenobiotic, toxicity evaluation etc., phytochemical evaluation \& biochemical activity ${ }^{[15]}$. Unique importance has been given to this phytochemical profile because it can proportionally impact on nature of Ayurvedic substances. In evaluating the consistency of botanicals, measurement of molecules for markers will serve as a significant variable ${ }^{[16]}$. For the detection and quality management of herbal medicines or products, various chromatographic techniques are most commonly used. Although there are several chromatographic approaches to accomplish segregation, the general thread is compound isolation with utilise of mobile phase \& stationary phase variations. GC, HPTLC, HPLC, HPLC-MS, GC-MS, NMR and TLC, etc., are part of the chromatographic process ${ }^{[17]}$. All of these approaches may support to measure the phytoconstituents that are found in complicated Ayurvedic oil integrated. A daunting task is process Pragmatic and creation assessment of organic components by chemo-profiling of herbal synthesis. Several facets of Ayurvedic medicine's quality management, standardisation and evaluation have been reported in Fig. 4. The key purpose of the efficiency assessment is to make confirm that Ayurvedic substances have a pre-set quantity, quality and therapeutic effects ${ }^{[18]}$.

\section{Chemo-profiling \& standardisation of Herbal drugs}

Chemo-profiling could be applied to many dependent classes or groups \& it is possible to create a chemical fingerprint to determine the phytoconstituents found therein. For product standardisation, chemical fingerprints may utilise to authenticated products, understand the categorisation of chemical components \& link molecular structure to biological activity ${ }^{[19]}$. Standardisation is often subject to the cautionary principle; i.e., whether the Manufacturers should not use similar indicators or techniques to achieve standardisation. Therefore, identical items may not be standardised at various levels with the same chemical marker or, whether the same marker is used, for different levels. Standardisation and certification of the finished product involves monitoring of both the consistency of the raw material and the production processes ${ }^{[20]}$. In maintaining clinical potential, medication synthesis and pharmacokinetics, effectiveness, lives and stability studies to rationalise utilise in medical field, marker analysis of standard drugs is a vital and important topic to be taken into account. This is an important part of conventional medicine, which means that the necessary volume of quality medication is administered. The main field for conventional formulations such as churnas, Bahamas, liquid orals, lehas, etc. is marker profiling ${ }^{[21]}$. Finger printing and marker substance evaluation are now becoming increasingly important for Ayurvedic formulation standardisation (Fig. 4). However, the therapeutic ingredients have not been thoroughly elucidated or easily controlled for most Ayurvedic drugs. Chemo-profiling of such Ayurvedic medications as seen in Table 2.

Several of the substances referred to in the ancient texts of the Indian method of ethnomedicine of several illnesses is derived from Ayurveda. It can be useful in designing new lead molecules by integrating the capabilities of the knowledge base of classical Ayurveda systems with spectacular potential of complex methods \& large data screening ${ }^{[22]}$. In Ayurvedic medicinal plants, a large amount of study has been conducted out on pharmacognosis, chemistry, pharmacology and clinical therapeutics. Various molecules also emerged from the experimental basis of Ayurvedic ${ }^{[23]}$. There are increasing incidences where, through improved interpretation of conventional expertise and clinical findings, the old molecules find fresh use. For e.g., forskolin is isolated from Coleus forskohl ii Willd, an alkaloid. Obesity and atherosclerosis are used by the Central Drug Research Institute (CDRI), Lucknow, India. Effective inhibitory antimicrobial, antirheumatic and cyclooxygenase action of phenolic, catechols and flavonoids through Semecarpus anacardium L., a big Ayurvedic herb. F. Promising sources were identified [24].

Study is a crucial instrument for spotting the microstructure of balanced plants' various components. Each plant has a completely different microstructure that makes it easier to discern plants that look similar but weigh square if distinct species. The natural phase of the skinny layer helps locate the gift of the chemical constituent inside the balanced plant that is paid with the plant's medicinal operation. GC, HPTLC, IR, MS, NMR and other equipment show detailed information on active compounds of healthy plants in addition to these HPLCs ${ }^{[25]}$. Numerous experiments in this area have even demonstrated if collected with organic solvent such as alcohol, ether, chloroform etc., the herb concentrate is simplified as a result of the bulk of the phytochemical compounds such as Chemical substance, glycosides, square analysis of the saponin gathered with the solvent or mixture of solvent. In specific compositions beginning from micromilligram to gram, every plant contains tied chemical components.

These molecules function either in the biological process or with 1 another antagonist and have a particular therapeutic outcome ${ }^{[26]}$. 
WHO Recommendations for standardised herbal formulations with accuracy

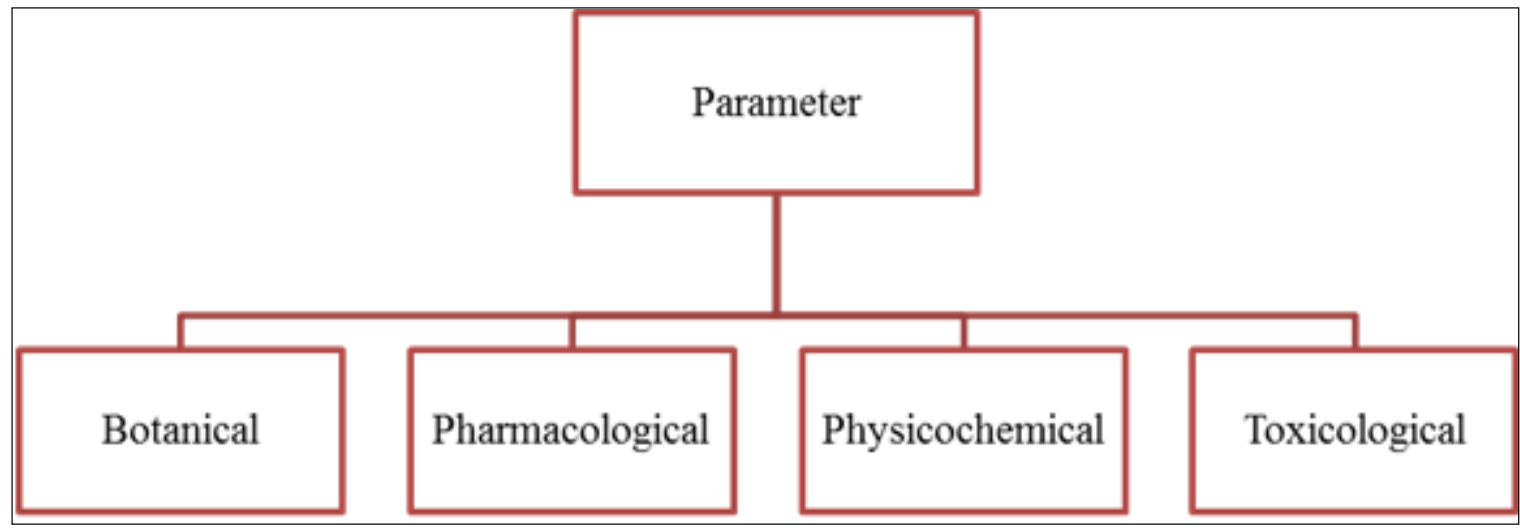

\section{Botanical Parameter}

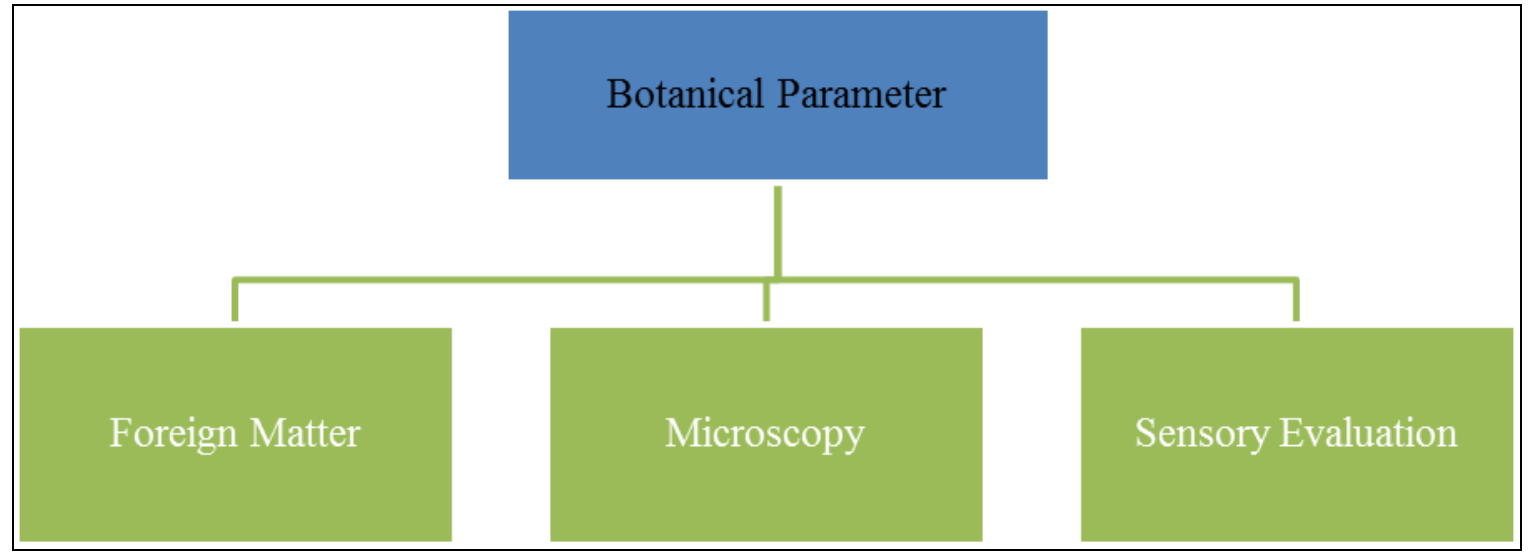

\section{Determination of Foreign Matter}

Drugs, such as mud, sand, stone, and foreign matter must be mould-free and insects free. Often foreign matter often consists of sections of the plant organ other than those provided by the WHO standards for the substance by itself or above the cap. The quantity of foreign substance should not greater than the recommended limit. It is important to weigh $100-500 \mathrm{~g}$ of the drug content, or to use the amount recommended by the WHO guidelines. Foreign matter can be observed by unassisted eye examination or by using a $6 \mathrm{X}$ power lens. Segregate the external matter and measure the current proportion. ${ }^{[27]}$

\section{Microscopy}

Histological analyses are performed from quite a thin substance section. It is possible to study in depth the features of cell membranes, its material, calcium oxalate crystals, fibres, starch grains, trichomes and vessels, etc. Quantitative microscopy and longitudinal tests are also significant histological components. Stomatal, index number, palisade proportional, number of vein-islet, starch grains size, fibres length, and microscopic assessment involves analysis or histological portion of substance are the different parameters analysed here. A decrease of phloroglucinol and a bright red dye of lignin hydrochloric acid. Mucilage with ruthenium red is dyed pink ${ }^{[28]}$.

\section{Sensory Evaluation}

Sensory drug assessment includes an assessment of a substance by appearance, odour, taste, etc. This assessment technique is the simplest and fastest way to determine the identification and purity of a specific sample and thereby guarantee the accuracy of specific test.

\section{Colour}

Colour showing unique nature of substance, i.e. the material originating from aerial component of plant, is typically green $\&$ material of the underground plant is generally green. The uncontrolled samples are analysed beneath diffused illumination or an artificial rays with a wavelength close to that of illumination for careful inspection.

\section{Odour and Taste}

Based on the experiences of humans, the scent and flavour of a crude substance are highly sensitive parameters. The definition of this function can, however, often create some complexities. Tiny amount of the sample will be tested by gradual \& regular absorption of air from specimen if the product is assumed to be harmless. It is demolished using bit of force on such specimens where no specific odour is perceptible, or where the specimen is considered to be harmful, by more acceptable methods, like spilling a low volume of boiling water onto the smashed sample placed in the beaker. The potency of the inhalation, like distinct, strong and weak is decided primary. Tiny part of sample was carefully and regularly inserted in the hand to taste the mouth over the substance ${ }^{[29]}$. 


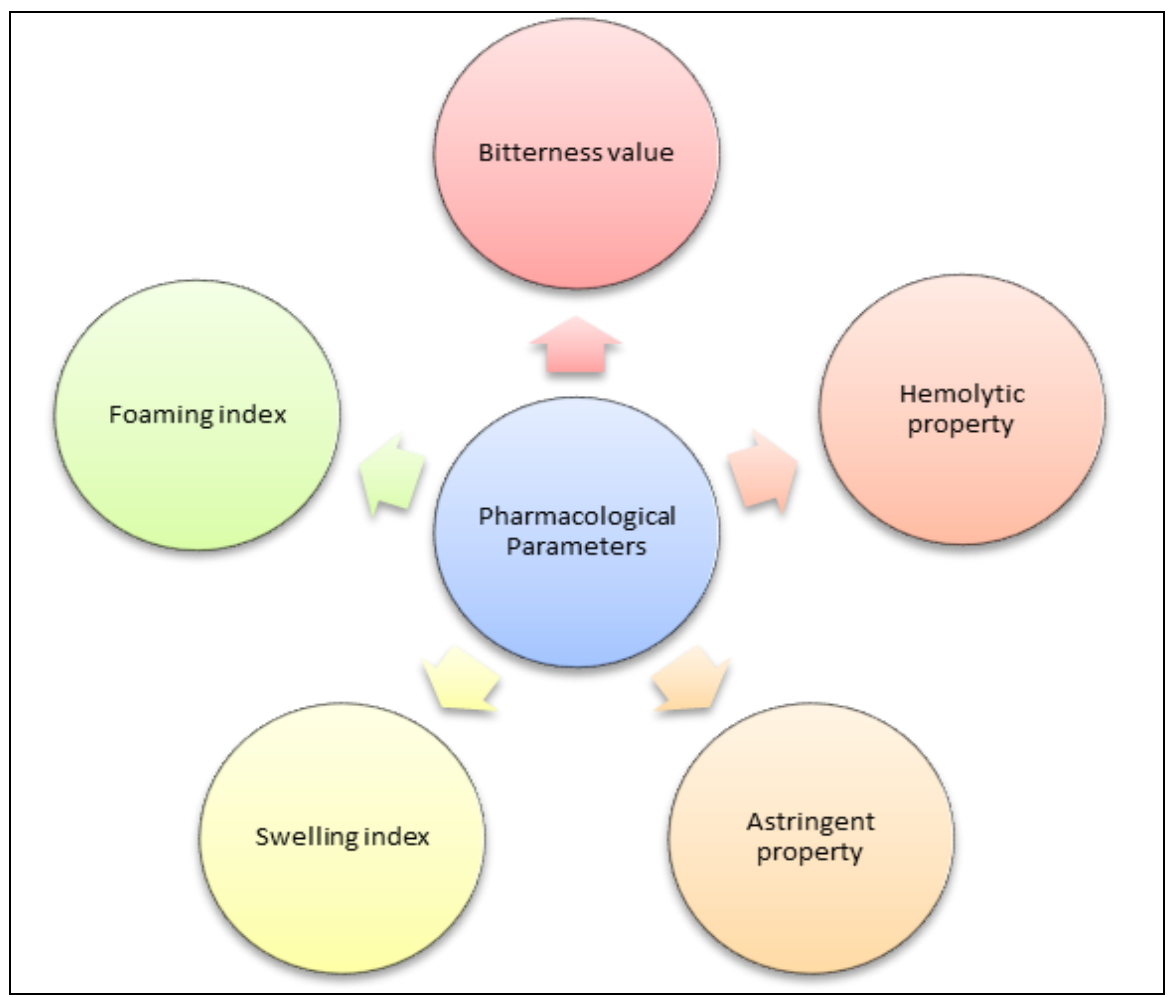

\section{Evaluation of Bitterness Value}

Therapeutically used pharmacological active herbs products which shows vigorous bitter form square analysis, mainly as savoury products. Its taste induces exudation, notably gastric juice, in the GIT. It is possible to chemically identify bitter compounds. However, as most of them consist of 2 or more representatives with varying level of bitterness, it is important to quantify overall bitterness by bite for first time. The bitter characteristics of the substance square quantify calculated through contrast between the side bitter abundance of the substances' related grade extract and the dilute reaction of the antimalarial medication coordination molecule R. Bitterness calculation is calculated in units equal to the bitterness of a $2000 \mathrm{ml}$ solution involves $1 \mathrm{gm}$ of quinine hydrochloride R. It after every tasting, clean fresh water can also performed as mobile for removing components of herb and for cleaning the teeth. Taste buds are increasingly unpleasant if water is used. Water toughness hardly has any major effect on bitterness.

\section{Evaluation of Haemolytic Property}

Saponin derives from the term Sapo, means soap, in Latin. The saponin-containing plant material has detergent properties. They are primarily distinguished by their Shrieking ability \& by their potential to stimulate haemolysis when applied to a blood mixture, saponin leads to alteration in the matrix of the erythrocyte, allowing emoglobin to migrate into the surrounding medium. Saponinin is found in several therapeutic plant materials, in particular those originating from the families Araliceae, Primulaceae, Caryophyllaceae and Dioscoreaceae ${ }^{[29]}$.

\section{Evaluation of Tannin}

These are commonly scattered in plants \& happen in cell sap, often of the vacuoles, in solution. Synthetically, all these substances that can be identified by tanning (test of the gold beater). To extract water by associated proteins in soluble substances that prone to photolytic enzymes, tannins are a material willing to turn animals into leather. This method is known as 'astringent' when tried to apply to living tissues and its purpose for the therapeutic agents of tannins ${ }^{[29]}$.

\section{Evaluation of Swelling Index}

It is that, under defined conditions, the amount in the index efficiency unit obsesses the swelling of 1 metric weight unit of substance. The decision is depends on addendum of water, as defined for each particular plant material in the test method. The substance is shook continuously for 1 hour with help of glass closed measuring cylinder and further allowed to keep for a required amount of duration. It then reads quantity of the combination. It's easy to blend the complete substance with the swelling agent, but cut or powdered material involves intense oscillation at defined periods to verify even separation of the content in the swelling department.

\section{Evaluation of Foaming Index}

The saponins are large molecule, storing the detergent property of the phytoconstituent. Based on its frothing property, Saponins often are characterised. Saponins are found in bioactive compounds of various groups. Once a binary compound stewing is agitated, many medicinal Foliage things contain saponins that may occur persistent foam. In terms of the foaming index, the foaming capacity of a water elixation of plant content and its final product is measured ${ }^{[29]}$. 


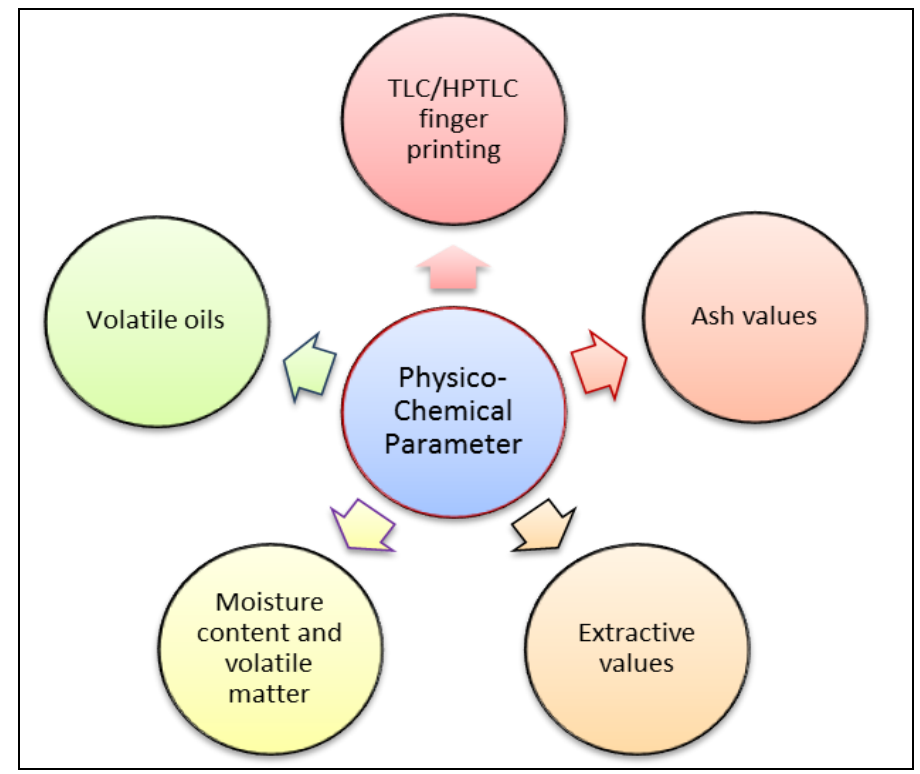

\section{TLC/HPTLC Finger Printing}

TLC is currently a key analytical instrument for a variety of natural substances for detection and quantification. The adsorbent like as silica gel $\mathrm{G}$ or $\mathrm{C}$ is covered on clean TLC plate to a thickness of $0.3 \mathrm{~mm}$ using an industrial spreader, the plate is enabled for half hour at $105{ }^{\circ} \mathrm{C}$ and used the solvent system range depends on the type of component to be examined. Further the advancing method recording case, the fixed spots are exposed by spraying with the required sleuthing agent. In the study of alkaloids, glycosides, isoprenoids, lipid elements, sugar and its derivatives and nearly each bio-components, TLC framework is effective. The RF values which differ based on the solvent's consistency, the quality of the material to be overcome, the structure of the solvent, the presence of defects, the adsorbent used, the solvent's polarisation, the product and adsorbent, etc. HPTLC methodology enables to find very low component intensity to be ppm latest diode-based transition image detector, enabling the Observational laboratory to have a separation in which all peak is a separated element ${ }^{[27,28]}$.

\section{Ash Value}

Ash left after heating can also evaluate the performance of a medication. There are four alternative approaches that calculate the ash.

1. Acid Insoluble Ash

2. Water Soluble Ash

3. Total ash

4. Sulphated ash

\section{Acid-Insoluble Ash}

Ash is heated for 05 min with $25 \mathrm{ml}$ of diluted HCL. The non - dissolve substance gathered on an ash less filter paper rinsed with warm water and ignited to a constant mass at a temp not crossed $450{ }^{\circ} \mathrm{C}$.

\section{Water-Soluble Ash}

Ash is soluble in purified water and non - soluble component is gathered on a filter paper of less ash and burned to a steady weight at $450{ }^{\circ} \mathrm{C}$. The mass of the dissolved portion of the ash is determined by minimising the weight of the non soluble part from those of the ash.

\section{Total Ash}

In a silica crucible, the powdered drug $(2 \mathrm{~g})$ is burned at a temperature not above $450 \mathrm{oC}$ until it is carbon free. The overall ash value is then cooled and measured to achieve it.

\section{Sulphated Ash}

It is the remaining product produced by heating complete ash along sulphuric acid \& cleaning non-soluble substance left on the filter paper. ${ }^{[30]}$

\section{Extractive Value}

The quantity of a residue formed in specific solvent by a drug is also an estimated analysis of the quantity of a specific compound present in the substance. To get the right and stable value, the substance should be extracted with various solvents in order to maximise its polarity.

\section{Water-Soluble Extractive Value}

Five $\mathrm{mg}$ drug powder is shaken vigorously in a closed flask with $100 \mathrm{ml}$ of purified water for 24 hours, shaken routinely for 6 hours and kept to stand for 24 hours. The filtrate is quickly filtered, precautioned against solvent loss, decanted in an assailed wide flat dish, dry at $105^{\circ} \mathrm{C}$, weighted and periodically weighed.

\section{Alcohol-Soluble Extractive Value}

Five $\mathrm{mg}$ drug powder is shaken vigorously in a closed flask with $100 \mathrm{ml}$ of alcohol (95\%) for 24 hours, shaken routinely for 6 hours and kept to stand for 24 hours. The filtrate is easily filtered, precaution against solvent failure, decanted in an assailed wide flat dish, dry at $105^{\circ} \mathrm{C}$, weighted and periodically weighed ${ }^{[31]}$.

\section{Viscosity}

The viscosity of an aqueous at mentioned temp is consistent and is an index of its formulation. It can also be used to standardise liquid medications as a form ${ }^{[28]}$.

\section{Melting Point}

The quality of the essential medicines is judged by 1 of the criteria. The melting point is very clear and stable in pure synthetic or phytochemical situations. Since the combined ingredients are found in crude medicines of plants or animals 
origin, some melting point ranges are defined.

\section{Solubility}

Solubility tests may suggest the existence of adulterants in a medication. Chloroform-soluble alkaloidal bases, while polar solvent-soluble alkaloidal salts. Alcohol and water remove the glycosides, while its moieties of aglycone are dissolved in non-polar solvents such as benzene or liquid ether.

\section{Optical Rotation}

The feature of spinning the axis of polarised light in its purest form or in the medium is present in many compounds. They are therefore defined to be optically active, and this behaviour is referred to as phase lag. Fluorescence can be rotated to the right (dextro rotator) or to the left (Levo rotator). The optical orientation is normally measured at $25{ }^{\circ} \mathrm{C}$ using sodium lamp as the medium of light ${ }^{[28]}$.

\section{Refractive Index}

For the assessment of plant oils and fixed oils, the assessment of the refractive index is a critical parameter. Where an oil involves any counterfeiting of other oils, the refractive index varies. That is a correlation between both the speed of light in the air as well as the speed of oil or material in the atmosphere.

\section{Evaluation of Moisture Content}

Assessment of humidity in volatile substance calculation, i.e. aqueous that dries out of product. For substances which tend to require water as the only volatile portion, this technique is far more suitable. Approximately $10 \mathrm{~g}$ of the substance (without interim rinsing) is correctly measured (within 0.01 gm) and dried in a painted evaporating dish to be carried out at $105^{\circ} \mathrm{C}$ for 5 hour. The sample is then weighed ${ }^{[27]}$.

\section{Evaluation of Volatile Oils}

Area unit for its characterised through ones odour, texture such oil \& willingness to volatilise at room temp. Synthetically, monoterpenes, sesquiterpenes and their oxygenated derivatives are built up of formulations. In some of these volatile oils, aromatic molecules predominate because they are deemed the "essence" of the organic matter and are often bioactive, and also called as "essential oils". Then, since it is more precise and explains the physical characteristics, the word "volatile oil" is favourable. The plant component is refined with aqueous and the vapour is gathered in a measured tube to evaluate the oil volume. The portion of the binary compound differentiates mechanically and reaches the filtration flask. If the volatile oil has a maximum mass density than or close to that of aqueous, leads to existence of emulsions, a solvent with a low volume fraction is hard to isolate from the water phase, then dissolved volatile oils would then move to the top of the water phase.

\section{Toxicological Parameter}

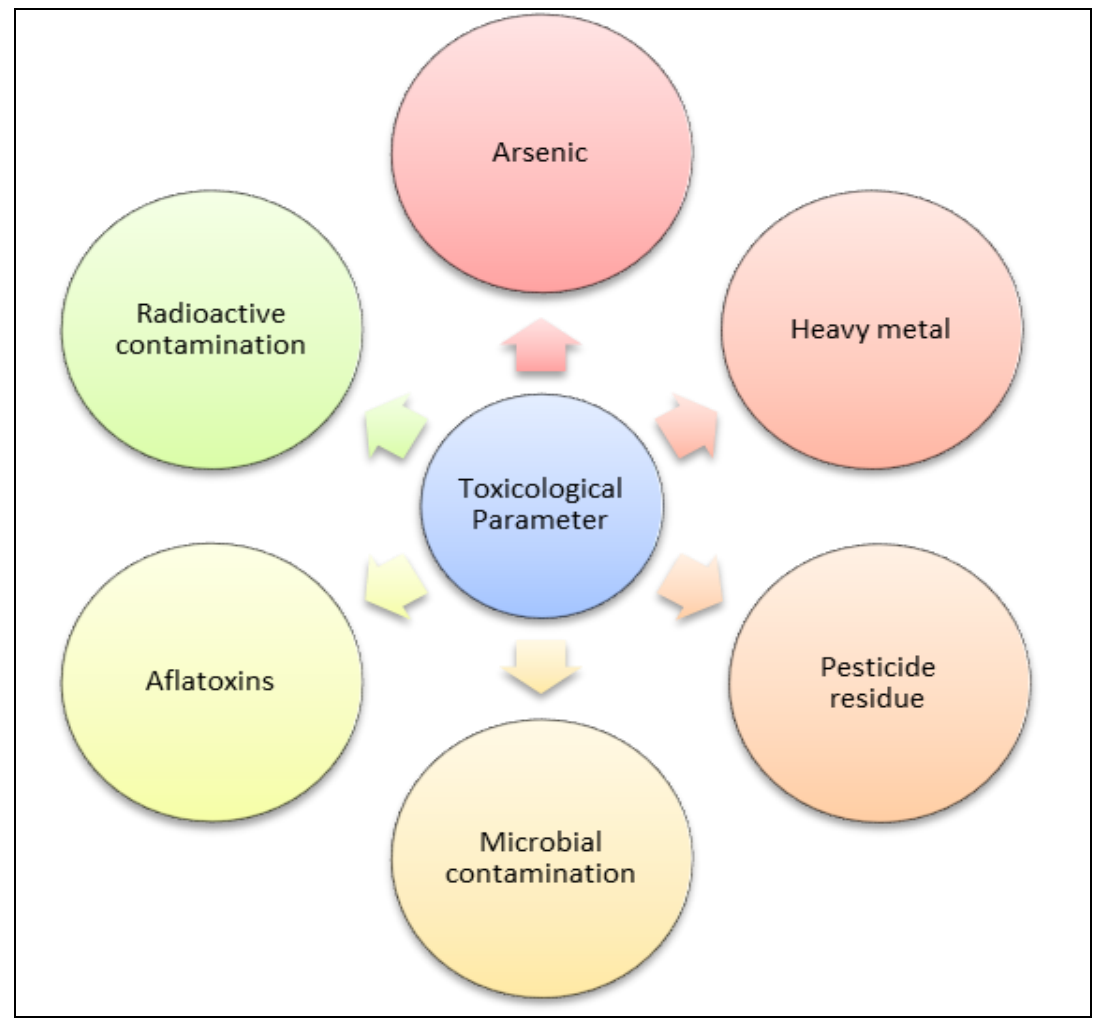

\section{Assessment of Arsenic and Heavy Metals}

Many effects can be ascribed to the toxicity of herbal plant products with arsenic and heavy metals, along with environmental air quality and pesticide residues. The quantity of arsenic in the therapeutic organic matter is calculated by pairing the colour with those of a normal stain.

\section{Assessment of Pesticide Residues}

Therapeutic herbs substances are vulnerable to the presence of synthetic compounds accumulating from farming activities, like as irrigation, soil management while planting and fumigant implementation while storage. Contaminants cause harmful effects such as eye irritation, lacrimation, lacrimation, cardiac diseases. It is also important to prevent the occurrence of these pollutants in traditional medicines ${ }^{[27]}$.

\section{Assessment of Microbial Contamination}

Owing to soil and environmental degradation, a significant amount of bacteria and moulds are usually found in medicinal plant products. Among others, bacteria producing aerobic 
spores play a role. Further pollution may be caused by the techniques of harvesting, handling and production. The key contaminating agents are E. Bobbin and other moulds. The standard of development and harvesting practises may imply the certainty of Escherichia coli and moulds.

\section{Assessment of Radioactive Contamination}

Possible level of ionising radioactive contamination could not be prevented because there are multiple causes, such found naturally radionuclides in the soil and the atmosphere. The radionuclide that would be available in the atmosphere depends since the consequences of a nuclear explosion might involve sustained and intermittent reactors, component, actinides, and release products. The existence \& hence strength of free radio nuclides can strongly disagree and depend on the availability. (Reactor, reprocessing facility, plant for the manufacture of carbon, isotope manufacturing unit, etc.) ${ }^{[29]}$.

\section{Ayurvedic Dosages Forms}

Ayurvedic medicines are derived from animals, plants and resources from a synthetic form. Based on their basic appearance, Ayurvedic dosage types are divided into 4 categories.

1. Soil dosage types- Bhasma, churna, gutika, kshara, lavana, mandura, parpati, pills, pisti, satva and vatika.

2. Semi-solid dosage types- Avleha, Ghrita, Lepa and Paka.

3. Liquid dosage types- Asava, Arka, Arista, Kwath, Dravaka and Taila.

\section{Standarisation of Various asavarista formulation}

Asava-arishta is a traditional type of liquid therapy in which natural element induction or decoction is fermented with sandhana kalpana-based conscience alcohol as defined in Ayurveda. Fermentation is a synthesis preparation process in which the medicinal characteristics of a collective of additives are obtained from either swarasa, newly concentrated plant juice or kwatha, decoction formulated in aqueous by means of biochemical or fermentation of microbes, \& anaerobic breathing in fluid ${ }^{[32]}$. Asava-arishta is desirable and recommended for its simple to receiver form, efficacy and prolonged utility in the therapy of a longer range of diseases.

\section{Approaches to Standardisation}

Standardisation of Ayurvedic products is an area of scientific and industrial interest. Large scale production need changes in preparations of classical Ayurvedic products. Satisfying needs of large scale production while adhering to principles of Ayurveda require careful considerations before adapting to new methods. Different parameters have been applied to standardise this self-generated alcohol based liquid classical dosage forms.

Over a period of several years different approaches to standardise asava-arishta have been undertaken. These quality control approaches can be broadly divided into 3 categories -

- Approach related to raw material and equipment

- Approach related to standardisation of manufacturing process

- Approach related to standardisation of properties and quality of the end product

\section{Approach related to raw material and equipment}

The quality of raw material, herbs and other ingredients used for these preparations have a strong bearing on the process and the finished product. Raw material for these preparations must be authenticated and examined for required quality. Testing of limits of heavy metals, microbial load and residual pesticides are envisaged as these will have impact on the main fermentation process and certain impurities may get retained through the process. It is desirable that the right storage conditions are followed for these raw material before being taken up for main production process. ${ }^{[33]}$ The type of equipment used, material used for fermentation and storage vessels, treatment mooted to the vessels, temperature and storage conditions factors that will impact the process.

\section{Approach related to standardisation of manufacturing processes}

The 3 most relevant parameters for the standardisation of asava - arishta are -

1. Effect of temperature

2. Fermentation time

3. Use of various vessels and fermentation conditions

\section{Temperature Impact}

Its impact the process of fermentation. Studies were carried out to understand the role of temperature and the timing of addition of sugar ingredients to the formulation indicate the following results.

A study was carried out on Draksharishta, wherein the $1^{\text {st }}$ batch was prepared by adding jaggery to the kashaya, the decoction of Ayurvedic component and mixed and warm for 2 minutes. Parallel the addition of jaggery was done only after cool down of decoction to about $40^{\circ} \mathrm{C}$ and further transferred to procelain jar and kept for fermentation.

Results showed that specific gravity, total solids and total sugars were lesser in the cold arishta than hot arishta. Cold arishta recorded an alcohol generated content of $7.64 \%$ whereas in the hot arishta there was no alcohol during filtration. There was not difference in tannin value. More titratable acidity and less $\mathrm{pH}$ values were found in arishta prepared from decoction with heat than the cold 1 from fresh juice. It is reasoned that in the hot Kashaya formulation, the yeast cells were destroyed because of higher temp; hence it was not desirable for the method of ferment. In cold Kashaya the yeast cells were not destroyed and hence it was good for fermentation process ${ }^{[34,35]}$.

\section{Fermentation time}

Effect of keeping the arishta over long periods was analysed for Amritarishta for 1-year. Conclusion showed that over increasing time, basic gravity, absolute solid count and sugar count decrease steadily. There was corresponding enhance in the alcohol content, recording maximum in 6 months. There was no variation in $\mathrm{pH}$ value ${ }^{[36]}$.

A study to find onset of fermentation process and the end of the fermentation process was undertaken. In Drakshasava it started on 5 th day and completed on $25^{\text {th }}$ day. ${ }^{[35,37]}$ During autumn and summer seasons, It has been identified that fermentation actually occurs within 6-day, 10-day in cold season \& 8-day in warm and wet seasons. In normal practise, in the warm tropical wheatear, 7-10-day are sufficient \& a prolonged of 30-day is enabled in a winter environment where bioactivity is less. ${ }^{[38]}$

\section{Use of various vessels and preparation conditions ${ }^{[39]}$}

Ayurvedic texts mention use of earthen pot and several others vessels; even of using gold vessel for fermentation process as in the preparation of Saraswatharishta. ${ }^{[40]}$ Materials like glass, aluminium, tinned-copper, stainless steel, porcelain jars 
and earthen pots were used for different preparations of asava - arishta where following results were observed.

A study conducted for comparing the use of different vessels in preparation of Amritarishta, indicated no change in analytical values of arishtas obtained from decoction prepared in different material vessels. However, the decoction formulated in aluminium vessel denotes aluminium availability. This research also revealed Tinned-copper vessels were a safer alternative for the method of ferment. ${ }^{[41]}$ Experimental preparation of Draksharishta [42] and Drakshasava ${ }^{[43]}$ in No noticeable variation in the quantity of alcohol formulation was seen in glass containers and earthen containers. It was observed that formulations in glass containers were much acidic than in earthen containers. No change was found in TLC pattern \& features in evaluation. Earthen pot showed more evaporation of water resulting in restricted product solubility. This altered $\mathrm{pH}$ affected the organisms' efficiency. ${ }^{[35]}$ According to Indian Pharmacopoeia sterilisation can be done by physical, chemical, gas and radiation of vessels.

\section{Outcome of the standardisation efforts}

Table 2: Outcome of Standardisation: Summary Chart

\begin{tabular}{|c|c|c|}
\hline Parameter & Outcome / Impact & Explanation / Remarks \\
\hline \multicolumn{3}{|c|}{1 (a) Raw material standardisation } \\
\hline Raw material & Authentication and storage & As per Pharmacopoeia and GMP guidelines \\
\hline \multicolumn{3}{|c|}{1 (b) Manufacturing processes } \\
\hline \multirow{3}{*}{ Temperature } & $\begin{array}{l}\text { Hot decoction: Lower } \mathrm{pH} \& \text { higher (titrable) acidity than cold } \\
\text { decoction }\end{array}$ & \multirow{3}{*}{$\begin{array}{c}\text { Optimum Temperature for Fermentation process is in } \\
\text { between } 20-35^{\circ} \mathrm{C}\end{array}$} \\
\hline & $\begin{array}{c}\text { Hot decoction: Yeast cells are destroyed because of higher } \\
\text { temperature; Not favorable for fermentation }\end{array}$ & \\
\hline & $\begin{array}{l}\text { Cold decoction: Yeast cells are not destroyed hence favorable } \\
\text { for fermentation. }\end{array}$ & \\
\hline Fermentation time & $\begin{array}{l}\text { Enhance in alcohol content with enhance in time for } \\
\text { fermentation. }\end{array}$ & $\begin{array}{c}\text { Fermentation time depends on geographic location and } \\
\text { season \& ingredients used (Liquid ingredients) }\end{array}$ \\
\hline Earthen pot & $\begin{array}{l}\text { There is more evaporation of water, limits solubility of } \\
\text { compound, alters pH medium and affects performance of } \\
\text { micro organisms }\end{array}$ & $\begin{array}{l}\text { Requires delicate handling, tendency of breakage \& } \\
\text { leakage }\end{array}$ \\
\hline Aluminium & Traces of aluminium and ferrous ions found in final product & Inappropriate for production \\
\hline Wooden vessel & Final Product: Denser in consistency & Absorption of liquid by wood \\
\hline Stainless steel & No significant variations in physicochemical parameters & Can be used for large scale production \\
\hline Glass vessels & $\begin{array}{c}\text { Final product in glass container is more } \\
\text { acidic than in earthen pot }\end{array}$ & Not convenient for large scale production \\
\hline Tinned copper & A better choice for fermentation & Can be used for large scale production \\
\hline \multicolumn{3}{|c|}{ 1(c) End product standardisation } \\
\hline \multirow{2}{*}{$\mathrm{pH}$} & $\begin{array}{l}\text { Affected by temperature and fermentation } \\
\text { Time }\end{array}$ & \multirow{2}{*}{$\begin{array}{l}\text { Affect the solubility, stability and quality of the } \\
\text { product Essential if the product is more } \\
\text { acidic or alkaline }\end{array}$} \\
\hline & $\begin{array}{l}\text { Utilisation of a buffer to control potential } \\
\text { changes in the solution } \mathrm{pH}\end{array}$ & \\
\hline Specific gravity & Temperature & $\begin{array}{l}\text { Affect the flow property } \\
\end{array}$ \\
\hline Total solid content & Total solid content: Fermentation Time & Solid contents are converted to fermentation product \\
\hline $\begin{array}{l}\text { Reducing sugar } \\
\text { percentage (RSP) }\end{array}$ & RSP reduces with fermentation time & $\begin{array}{l}\text { When the percentage remains stable, The finalisation } \\
\text { of the fermentation reaction is an indicator for } \\
\text { determining }\end{array}$ \\
\hline $\begin{array}{l}\text { Non-reducing sugar } \\
\text { percentage (NRSP) }\end{array}$ & $\begin{array}{l}\text { NRSP varies with temperature and with fermentation time } \\
\text { (Due to presence of microorganism) }\end{array}$ & $\begin{array}{l}\text { It is an indicator for assessing the end of the } \\
\text { fermentation reaction whether the percentage stays } \\
\text { constant. }\end{array}$ \\
\hline \multirow{2}{*}{ Total sugar percent } & \begin{tabular}{|c|} 
Total percentage of sugar at fermentation time \\
\end{tabular} & \multirow{2}{*}{$\begin{array}{l}\text { Also depends on type of sweetening agent added, } \\
\text { Converted to alcohol }\end{array}$} \\
\hline & Is less in finished product and varies with type of vessels used. & \\
\hline Ash value & More in market sample than lab method & Indicative of adulteration \\
\hline \multirow[t]{2}{*}{ Alcohol percentage } & $\begin{array}{l}\text { Enhanced with reference to time duration for } \\
\text { Fermentation }\end{array}$ & $\begin{array}{l}\text { Important with respect to } \\
\text { therapeutic activity and stability }\end{array}$ \\
\hline & When prepared in glass vessel & Product may become acidic \\
\hline $\begin{array}{c}\text { Thin layer } \\
\text { chromatography }\end{array}$ & $\begin{array}{l}\text { Identification of Phytoconstituents: as a } \\
\text { Standard to compare } \\
\end{array}$ & $\begin{array}{l}\text { Qualitative Standardisation } \\
\text { technique }\end{array}$ \\
\hline $\begin{array}{l}\text { High performance } \\
\text { liquid chromatography }\end{array}$ & $\begin{array}{l}\text { Comparison with marker compound, } \\
\text { isolation of functional group used as standard parameter }\end{array}$ & Quantitative Standardisation technique \\
\hline
\end{tabular}

Standardisation protocols of different formulations of asavarista are outlined:

\section{Abhayarista}

A similar analysis of Abhayarista derivatives found which key polyphenolic substances of Terminalia chenula were hydrolysed to its various monomers \& so after fermentation, the volume of chebulinic acid, gallic acid and ethyl gallate enhanced proportional to the decoction calculated through HPLC ${ }^{[44]}$. The ethanol yield was estimated by the GC technique of 4 marketed Abhayarishta formulations ${ }^{[45]}$. The ethanol solution was estimated through redox titration and the GC process in this other test. UV and HPLC techniques measured gallic acid, the primary ingredient element of Terminalia chebula ${ }^{[46]}$.

\section{Amritarista}

Amritarista was formulated as per the Herbal medicine Types of India employing pure and approved components and was examined using the TLC process. Under UV light, the solvent system revealed a single spot of yellowish-brown colour, n- 
butanol: glacial acetic acid:water (4:4:2), when the chromatogram was treated to alcoholic $\mathrm{KOH}^{[47]}$.

In Parallel research, the HPTLC approach was introduced to use luteolin and apigenin as marker compounds to standardise the marketed Amritarishta formulation. Using tolune:ethyl acetate:glacial acetic acid $(5: 4: 1)$ as moving fluid step, 2 ratios (1 and 2) of the ethanol concentrated of the mentioned synthesis and regular luteolin \& apigenin were added to the HPTLC.

The RF count of both apigenin (0.81) and luteolin (0.64) were observed to be similar in study and in comparative norm, respectively ${ }^{[48]}$.

\section{Aravindasava}

Aravindasava was processed and examined through TLC according to the conventional approach. In solvent system, nbutanol:glacial acetic acid:water (4:4:2), Aravindasava showed 3 marks of yellowish-grey, grey \& violet colour \& 2 brown marks in UV light at $365 \mathrm{~nm}$ while spraying with alcoholic $\mathrm{KOH}$ solution. ${ }^{[4]}$

\section{Arjunarista}

A reverse-phase HPLC approach was used to classify phenolic substance such as ellagic acid, gallic acid, ethyl gallate, quercetin and kaemmpferol and compared the existence of these marker substances between drug decoction and finished formulation. These marker substances did not interact with other constituents found in the mixture because they were present at very low concentrations. A comparative analysis of 2 chromatograms (decoction and preparation) found that during fermentation, the concentrations of gallic acid and ellagic acid enhanced, likely due to ellagitannin and gallitannin hydrolysis. [49] Terminalia arjuna TLC demonstrated the existence of ellagic acid. [50] In another report, colorimetric analysis estimated the volume of gallic acid. ${ }^{51]}$ HPTLC was used to evaluate the sum of ellagic \& gallic acid in Arjunarista-T (formulated by eternal system), Arjunarista-M (formulated by advanced system) and its marketable preparation ${ }^{[52]}$.

\section{Ashokarista}

Ashoka's bark extract was standardised through TLC as reference using catechin ${ }^{[53]}$. TLC and in-house preparation tests of the branded products (Baidhyanath, Dabur, Zandu) revealed the existence of kaempferol closer to the regular kaempferol [54]. A liquid chromatograph bound with a photodiode array detector which detect different forms of phenolic substances in Ashokaritsa ${ }^{[55]}$. On a UV spectrophotometer, total phenolics, total alkaloids, total flavonoids and total saponins were calculated in the marketed and in-house Ashokaritsa formulation.

In the marketed formulation, overall phenolic, flavonoid and alkaloid substances were observed to be greater than in the inhouse preparation. Whereas the cumulative substances of saponin in sold preparation were found to be very lower relative to the in-house formualtion. These discrepancies in quantity of synthetic ingredients may be attributed to differences in the geographical areas of crude products and different crude products ${ }^{[56]}$. Ashokaritsa's TLC shows 3 yellowish-grey, grey and violet spots in the n-butanol:glacial acetic acid:water solvent method (4:4:2) and 1 brown fluorescent mark in UV light at $365 \mathrm{~nm}$, that turned red post spraying through alcoholic $\mathrm{KOH}^{[47]}$.

\section{Ashwagandharista}

A standard HPLC method with aferin-A and withanolide-A standard was used to standardise Ashwagandharista [57].
Ashwagandha root powder TLC revealed 1 blackish-brown mark in benzene solvent phase: ethyl acetate $(9: 1)^{[58]}$ Ashwagandharista was standardised for biomarker estimation with anolide-A by FTIR and HPTLC methods. Atomic absorption spectroscopy has found heavy metals like lead, mercury, cadmium and arsenic. The existence of functional groups similar to Ashwagandha powder was identified in FTIR formulation studies and the existence of the biomarker withanolide-AA was seen in the HPTLC analysis [59]. Chromatographic methods were used to test Ashwagandharista, developed by 3 separate firms. The existence of anolide-D was identified by HPTLC in ashwagandharista by Dabur Ashwagandharista by Baidyanath, but not clearly evident in Ashwagandharista by Arya Vaidya Pharmacy due to band overlap [60]. Ashwagandharista's TLC showed just 3 spots through UV light with the n-butanol:glacial acetic acid solvent system: water $(4: 4: 2)^{[47]}$.

\section{Ayaskrti arista}

For the analytical analysis, its dosage form of 3 separate units, developed by Arya Vaidya Sala, was obtained. Gallic acid was quantitatively estimated through the solvent scheme toluene:ethyl acetate:acetic acid:water acid in ethyl acetate extract formulation using the HPTLC process $(3: 3: 0.8: 0.2)$ [61].

\section{Balarista}

The total content of phenolics, alkaloids, flavonoids and saponins in marketed and in-house Balarista formulation was defined using a UV spectrophotometer. It observed that total phenolic was lower and total flavonoid was higher in in-house formulation, while the total alkaloid content was much lower comparison to marketed product in the in-house preparation relative to the total alkaloid content. In in-house preparation, the overall amount of saponin was found to be almost twice that of the advertised formulations. Because of variation in the area or location of crude products and different processing techniques, the difference in the values of phytoconstituents may have developed ${ }^{[56]}$. Toxic alcohol residue such as methanol was observed to be missing in a different review, which was verified by GC-MS analysis. In checked mixture, the existence of flatoxins and heavy metals was also observed to be lacking ${ }^{[62]}$.

At $365 \mathrm{~nm}$ with solvent system n-butanol:glacial acetic acid: water, TLC revealed 3 spots under UV light $(4: 4: 2)^{[47]}$.

\section{Brahmiarista}

HPTLC was analysed for the commercialised formulation of Brahmiarista using bacoside-A as the marker compound. When used in toluene:ethyl acetate:methanol:glacial acetic acid \& sprayed with 10 percent sulphuric acid in alcohol, the mixture did not display any peak parallel to bacoside-A, The unavailability of Bacopa monnieri as the primary component was confirmed, but certain alternatives may be used ${ }^{[63]}$.

\section{Chandanasava}

The impact of time on Chandanasava fermentation \& storage was analysed \& assessed by TLC. It was cooked in an earthen pot as per Ayurvedic Pharmacopoeia process and the pot was opened and the contents were examined at an interval of 15 days. The formulation that was deposited after fermentation in a glass bottle was subject to the TLC analysis. TLC did not demonstrate any distinction between the formulation obtained in an earthen pot after $30 \mathrm{~d}$ of fermentation and the substance kept in a glass bottle for three months ${ }^{[64]}$. In order to validate 
the batch-batch accuracy, the HPTLC chromatogram of this drug indicated a position at similar location for all slots ${ }^{[65]}$. GC-MS research was conducted to demonstrate the unavailability of harmful additives such as methanol, flatoxins \& heavy metals in the sold Chandanasava formulation ${ }^{[62]}$. TLC revealed 3 spots with the solvent n-butanol:glacial acetic acid:water (4:4:2) in UV light at $365 \mathrm{~nm}$, when spraying with alcoholic $\mathrm{KOH}^{[47]}$.

\section{Dasamularista}

In a comparative analysis, by making up to half to $3 / 4$ th ability of the package, Dasamularista was formulated by the same height, shape \& ability of the earthen pots, stainless steel vessel and porcelain jar. TLC using the butanol, acetic acid and water solvent method $(63: 17: 10)$ revealed 5 spots in various preparations. The pot make up to $3 / 4$ th potential was found to be most appropriate for fermenting Dasamularishta from various analytical and physico-chemical study findings [66].

A UV spectrophotometer measured the existence of complete phenolics, alkaloids, flavonoids \& saponins in sold Dasamularishta \& in-house preparations. In the in-house preparation, the amount of overall phenolic content was found to be higher than in the marketed product, while the total flavonoid, alkaloid and saponin content was lower in the inhouse preparation than in the marketed product. These disparities may have been caused by changes in origins areas of crude products and various techniques used for its production ${ }^{[56]}$. When sprayed with alcoholic $\mathrm{KOH}$, TLC revealed 2 marks in UV light with solvent phase n-butanol:glacial acetic acid:water $(4: 4: 2)^{[47]}$.

\section{Draksharista}

For comparative quantification of quercetin and rutin, the HPTLC method was developed in Draksharista form formulated by conventional, advanced methods and in marketed form as well. For calculation of quercetin and rutin, mobile phases like toluene:ethyl acetate:methanol:formic acid (6:3:0.2:0.4) and ethyl acetate:n-butanol:formic acid:water (10:6:2:2) were taken respectively. In addition, formulations prepared by conventional methods have demonstrated that they keep more quercetin and rutin in comparison to those formulated by different methods ${ }^{[67]}$.

The HPTLC profile of the branded Draksharista and the crude products utilise in the formulation was done by Pillai et al. Using gallic acid, catechin and resveratrol as marker substances with the solvent framework toluene:ethyl acetate:formic acid (6:4:0.8), toluene:ethyl acetate:formic acid (5:6:1) \& chloroform:ethyl acetate:formic acid (5:4:1), respectively, the alcohol concentrate of 2 marketed products and all crude products is subjected to HPTLC study.

As specified in the Ayurvedic Formulary of India, the Draksharista contained all components and also the marker substances ${ }^{[68]}$. For measurement of gallic acid, catechin and resveratrol, the quality approved HPTLC approach was used in 3 slots of Draksharista in-house product and 2 batches of marketed product (M1 and M2) with similar extract \& solvent phase as already stated by Pillai et al. In contrast with advertised formulation, gallic acid was observed more in the in-house product (Slot-3). In the in-house formulation (batch1), Catechin has been found to be more, while in the sold formulation which is much low (M2). In in-house product, resveratrol was observed to be much (slot-1) ${ }^{[69]}$.

In Draksharista product prepared by conventional and modern processes, gallic acid \& catechin were also quantified by
HPTLC, \& in marketed product as well. It was found that quantity of gallic acid \& catechin was observed to be higher in traditionally formulated product ${ }^{[70]}$.

\section{Drakshasava}

Drakshasava, using UV spectroscopy, was formulated and did quantitative analysis of phytoconstituents. The quantitative analysis of overall phenolic and tannins denotes that the amount were 6.34 and $1.18 \mu / \mathrm{ml}$ respectively. There was no alkaloids in the formulation ${ }^{[71]}$.

\section{Jirakadyarista}

RP-HPLC has identified two primary substances, apigenin-7O-[galacturonide (1->4)-O-glucoside] and luteolin-4'-O[glucoside-7-O-galacturonide] from Jirakadyarista. 7-Oglucosides of luteolin \& apigenin were hydrolysed while the fermentation process was performing, to enhance the volume of luteolin and apigenin in preparation. It was also found that by jaggery and other plant products, monomeric phenolic substances \& 5-hydroxymethyl furfural were added into the product ${ }^{[72]}$.

\section{Kanakasava}

Three Kanakasava brands were acquired from the market and evaluated using specific gravity and GC methods for ethanol content. The outcome denotes that the ethanol extract measured by both techniques was proportional and the results were observed to be under limit ${ }^{[73]}$. In the ethanol fraction of Kanakasava, gallic acid and ethyl gallate is quantitatively estimated by HPTLC through toluene:ethyl acetate:formic acid:methanol (3.5:3.5:0.8:0.5) as the moving stream ${ }^{[74]}$.

\section{Kharjoorasava}

A conventional approach was used to prepare Kharjoorasava using Dhataki pushpa (Woodfordia fruticosa) and Hapusha (Juniperus communis) as a fermenter that was tested by TLC. Due to the existence of related secondary metabolites, the findings showed close similarities between the 2 formulations. The bio-active substance were converted in the formulation medium during the fermentation process because of low developments in reaction ${ }^{[75]}$.

\section{Kumaryasava}

Kumaryasava's alcohol concentration was measured using both the basic gravity and the GC system. The effect was a steady decline in ethanol content when Kumaryasava was placed in various containers, which may be due to vaporisation when the container was opened. Asava and arista formulations must either be ingested in less amount of period or smaller amounts could be made for the formulation. It was observed that the overall phenolic content was 0.1 per cent ${ }^{[76]}$. As per Dash et al. ${ }^{[77]}$ The average phenolic compound cap should equal or more than $0.06 \%$ w/vv.

Kumaryasava was subjected to UV and FTIR spectroscopic analysis in another sample. Aloin was extracted from various Kumariasava fractions and used as a marker for instrumental methods of HPTLC standardisation. Petroleum ether, benzene, chloroform and ethyl acetate is fractionated with kumaryasava. The chloroform fraction revealed 5 spots, confirming the existence of 5 components, of which 3 were divided by preparative TLC components. Flavonol, isoflavones and anthraquinone were determined to be Fraction III, IV and V, respectively. The peaks suggesting the existence of quinones were provided by UV and IR spectra of fraction V. For regular standardisation of Kumaryasava, UV, 
IR and HPTLC fingerprints of fractions III-V may be used. Fraction V, which provided 2 peaks, was subjected to HPLC analysis. Aloin, an anthraquinone glycoside reported to be present by updated Borntrager examination, TLC and HPLC analysis in fraction V. TLC, HPTLC and HPLC review also compared both fraction $\mathrm{V}$ and regular marker aloin well, indicating the role of aloin in Kumaryasava formulation. This may be an easy, precise and continuous approach for Kumaryasava analysis ${ }^{[78]}$.

\section{Kutajarista}

Kutajarista used a solvent phase with ethyl acetate, n-hexane $\&$ triethyl amine (70:24:6), HPLC with methanol and aqueous (95:5) and HPLC-MS with acetonitrile \& water (95:5) by conessine as a biomarker to standardise HPTLC. The HPTLC alkaloidal ratio chromatogram of its revealed 3 well-found marks. After spraying with Dragendorff's reagent, the marks with RF 0.40 matched normal conessine. The occurrence of conessine was also confirmed by HPLC-MS in the alkaloidal fraction. During retention time of $12.5 \mathrm{~min}$, peak of regular conessine also emerged in extract and displayed equal mass fragmentation. The HPLC alkaloid fraction determination of formulation gave 1 major peak with a retention time of 4.17 min that corresponded to HPLC normal conessine analysis [79]. The culture-independent 16SrRNA gene clone library method analysed the microbial existence of Kutajarista at the initial fermentation stage. Gallic acid on 0-day, ellagic acid \& gallic acid on $8^{\text {th }}$-day and gallolyl derivatives \& ellagic acid on $30^{\text {th }}$-day were recovered during fermentation, as analysed through HPLC-MS analysis ${ }^{[80]}$. When sprayed with alcoholic $\mathrm{KOH}$, TLC revealed 2 marks in UV with solvent method nbutanol:glacial acetic acid:water $(4: 4: 2)^{[47]}$.

The function of various container types and preparation methods in Kutajarista has been investigated. Kutajarista was prepared in various storage made of clay, wood, stainless steel and plastic using two processes, traditionally using Dhatakipuspa as fermenter and advance using yeast as fermenter. Fermentation began on $2^{\text {nd }}$-day with the yeastcontaining formulation as fermenter and on $5^{\text {th }}$-day with the Dhataki puspa-containing formulation as fermenter. The existence of hormones, triterpenoids, proteins, tannins and alkaloids was shown through qualitative phytochemical formulation studies. The UV determination shows the largest percentage of alkaloids and tannins in stainless steel and plastic containers with all test prepared using conventional and alternate processes ${ }^{[81]}$.

\section{Lohasava}

This was formed and examined by TLC as per Ayurvedic Formulary of India. The TLC analysis shows 2 marks; violet \& grey in UV light using the n-butanol:glacial acetic acid:water solvent method $(4: 4: 2)$ when sprayed by alcoholic KOH. [47] The GCC calculated the ethanol content of Lohasava. On the PerkinElmer Optical Emission Spectrometer, Optima 2100DV, heavy metal analysis was conducted. Lead and mercury were found to be missing, while arsenic and cadmium were exist within the World Health Organization's stated cap (WHO). In Lohasava ethyl acetate extract, gallic acid was quantitatively measured using toluene:ethyl acetate:formic acid (10:7:1) as the mobile step by HPTLCC ${ }^{[82]}$.

\section{Mustakarista}

The GC approach for quantifying alcohol concentration was tested by four distinct brands of branded Mustakarista formulations. Relevant gravity and studies have indicated a steady decrease in the content of auto-formed ethanol in storage that could be because of evaporation following frequent release of bottle. Compared to the defined gravity method, the GC method produced detailed and reliable performance. Variations in the alcohol content of various containers used in the processing process have been observed. For 2 branded formulations of Mustakarista, the overall phenolic content was found to be 0.09 and 0.08 percent. ${ }^{[75]}$

\section{Saraswataristam}

The Saraswataristam formula FTIR continuum showed a range of peaks at $400-4000 \mathrm{~cm}-1$. Because of the inclusion of $\mathrm{OH} \&$ a based group of alternate component in mixture, a large peak found at 3446 and $3442 \mathrm{~cm}-1$. In centella powder that was the primary component in mixture, a similar peak was observed. HPTLC formulation research has indicated a plateau of asiaticoside ${ }^{[83]}$.

The HPTLC approach was developed in the Vidangarista formulation for measurement of the biomarkers gallic acid \& conessin $^{[84]}$. It is a polyherbal mixture referred to and used as an anthelmintic in the Ayurvedic Formulary of India. The Ayurvedic medicine industry is growing increasingly in India, and more herbal drugs are being launched on the market. Through implementing proper standardisation procedures, the purity and effectiveness of these formulations must be guaranteed. Traditional standardisation approaches are considered to be inadequate to verify these formulations, thus playing a critical role in current advanced techniques. All developed nations worldwide could well embrace Indian Ayurvedic formulations if they are formulated through standard methods \& standardised through advanced techniques. In the standardisation of Ayurvedic formulations, fingerprint profiles obtained by different chromatographic techniques play a significant role. To performing as quick and precise instruments for plant medicine standardisation, it is important to establish advanced hyphenated techniques. In the quality management of Ayurvedic formulations, the blend of qualitative fingerprint \& quantitative multicomponent evaluate works as a unique $\&$ reasonable process. It can be inferred from this analysis that there was great scope for the creation of analytical techniques for authentication of most asava-arista Preparation. Standardisation procedure could be developed by hyphenated methods like GCMS, LC-MS, LCNMR, \& used for the assessment of asava-arista multidrug preparation where tiny amounts of marker substance are present. For several other Ayurvedic formulations, modern analytical methods of standardisation have yet to be established.

\section{References}

1. Verma S, Singh SP. Current and future status of herbal medicines. Veterinary World 2008;1(11):347.

2. Huang Y, Wu Z, Su R, Ruan G, Du F, Li G. Current application of chemometrics in traditional Chinese herbal medicine research. J Chromatogr B 2016;1026:27-35.

3. WHO. Guidelines for assessing quality of herbal medicines with reference to contaminants and residues. Geneva: World Health Organization 2007.

4. Parasuraman S, Thing GS, Dhanaraj SA. Polyherbal formulation: concept of ayurveda. Pharmacogn Rev 2014;8(16):73-80.

5. Garg S, Bhutani KK. Chromatographic analysis of Kutajarista - an ayurvedic polyherbal formulation. Phytochem Anal 2008;19(4):323-8. 
6. Shi X, Zhang K, Xue N, Su L, Ma G, Qi J et al. Differentiation of genuine Inula Britannica L. and substitute specimens based on the determination of 15 components using LC-MS/MS and principal components analysis. Food Chem 2013;141(4):4019-25.

7. Song S, Ma J, Tian Q, Tong L, Guo X. Hexachlorobenzene in human milk collected from Beijing, China. Chemosphere 2013;91(2):145-9.

8. Mukherjee PK. Promotion and development of botanicals with international coordination, in: Mukherjee, P.K. (Eds.), Promotion and Development of Botanicals with International Coordination: Exploring Quality, safety, Efficacy and Regulations. Allied Book Agency, Kolkata 2005,1-9p.

9. Tavhare SD, Nishteswar K. Collection practices of medicinal plants - Vedic, ayurvedic and modern perspectives. Int. J. Pharm. Biol. Sci. Arch 2014;5:54-61.

10. Chandra TR, Suresh C, Nigamanand B, Deep KG. Guidelines for collection of raw drugs and characteristics of collected material w.s.r. to Ayurveda. Uniq. J. Ayur. Herb. Med 2014;2:4-7.

11. Cordell GA. Phytochemistry and traditional medicine - a revolution in process. Phytochem. Lett 2011;4:391-398

12. Mukherjee PK, Bahadur S, Harwansh RK, Nema NK, Bhadra S. Development of traditional medicines: globalizing local knowledge or localizing global technologies. Pharma Times 2013;45:39-42

13. Lavekar GS. Scientific validation of drug development and clinical research in Ayurveda. AYU. PM 2006;70:6685.

14. Mukherjee PK, Harwansh RK, Bahadur S, Banerjee S, Kar A. Evidence based validation of Indian traditional medicine - Way forward. World J. Tradit. Chin. Med 2016;2:48-61.

15. Mukherjee PK, Saha BP. Quest for GMP for the production of quality botanicals, in: Mukherjee, P.K., Verpoorte, R., (Eds.), GMP for botanicals regulatory and quality issues on phytomedicine. Eastern Publishers, New Delhi 2003,165-90p.

16. Folashade KO, Omoregie EH, Ochogu AP. Standardization of herbal medicines - A review. Int. J. Biodiver. Conserv 2012;4:101-112.

17. Mukherjee PK, Kumar V, Kumar NS, Heinrich M. The Ayurvedic medicine Clitoria ternatea from traditional use to scientific assessment. J. Ethnopharmacol 2008;120:291-301.

18. Mukherjee PK, Venkatesh M, Maiti K, Mukherjee K, Saha BP. Value added herbal drug delivery systems perspectives and developments. Indian J. Pharm. Educ. Res 2009;43:329-337.

19. Mukherjee PK, Houghton PJ. The worldwide phenomenon of increased use of herbal products: Opportunity and threats, in: Mukherjee, P.K., Houghton, P.J. (Eds.), Evaluation of Herbal Medicinal Products Perspectives on Quality, Safety and Efficacy. Pharmaceutical Press., London 2009,3-12p.

20. Mukherjee PK, Ponnusankar S, Pandit S, Hazam PK, Ahmmed M, Mukherjee K. Botanicals as medicinal food and their effects on drug metabolizing enzymes. Food Chem. Toxicol 2011;49:3142-3153.

21. Mukherjee PK. Evaluation of Indian traditional medicine. Drug Inf. J 2001;35:623-631.

22. Patwardhan B, Vaidya ADB, Chorghade M. Ayurveda and natural product drug discovery. Curr. Sci 2004;86:789-99.
23. Patwardhan B. Ethnopharmacology and drug discovery. J. Ethnopharmacol 2005;100:50-52.

24. Patwardhan B, Vaidya ADB. Natural Product drug discovery: Accelerating the clinical candidate development using reverse pharmacology approaches. Indian J. Exp. Biol 2010;48:220-227.

25. Narayana DBA. Approaches to Herbal Formulation Development 1993;9:6-11.

26. Krishnamurthy LV, Sane RT. Ayurvedic Bhashmas on the basis of morden Analytical Instrumentation Techniques, Research journal of chemistry and environment 2001;5(4):65-67.

27. Agarwal SS, Paridhavi M. Herbal drug technology, Pulished by Universities press privete India 2007,629676

28. Kokate CK, Purohit AP, Gokhale SB. Text book of Pharmacognosy, Nirali prakshan, 1st Edition 82, 44, 107113

29. Mukherjee PK. Quality control of herbal drug, Evaluating Natural Products and Traditional Medicine, 1st Edition 2019,784

30. Ansari SH. Standardization of crude drugs "Essential of pharmacognosy" 1st Edition 2005,190,470

31. Charak. Charak Samhita by Agnivesha. (ed. Shashtri SN). Sutra Sthan 28/284, Varanasi; Chaukhambha 1962.

32. Sushruta. Sushruta Samhita. (With Dalhana's Commentary). (ed. Vaidya Jadavaji Trikamji Acharya). Sutra Sthan. 7th ed. 194., Varanasi; Chaukhambha 2002;45:211.

33. Sameet M, Swati M, Balian S. Modern Concept of Storage and Packaging of aw Herbs used in Ayurveda. International journal of research in Ayurveda and Pharmacy 2014;05(02):242-245

34. Indira Ammal MJ et al. Standardization of AsavaArishta-V Effect of adding Jaggery to the Kashaya Under Hot and Cold Conditions, Journal of Research Ind. Medicine Yoga \& Homeopath 1976;11(1):109-111.

35. Anand C, Neetu S, Madhuri D, Asmita W. A Progressive Review of Sandhana Kalpana (Biomedical Fermentation): An Advanced Innovative Dosage Form of Ayurveda. AYU 2011;32(3):408-418

36. Sheshadri C, Nambisan PN. Standardization of Asava/Arishtas-IV Effect on keeping the Arishta over long periods. $\mathbf{J}$ of Res Ind. Med Yoga and Homeo 1976;11(2):111-112

37. Muzaffer A, Sathiavasan KK, Paranthaman M, Purushothaman KK. Comparative studies on Fermentation and Standardization of Drakshasava. Journal of Research in Ayurvedic, Sidhha 1981;3:1-2.

38. Sekar S, Mariaappan S, Wollgast V, Anklam. Traditional Fermented Biomedicines, Arishtas and Asavas from Ayurveda. Indian Journal of Traditional Knowledge 2008;7(4):548-556

39. Shishir KP, Samanta MK. Formulation and Evaluation of Sugar Free Ashwagandharishta for Diabetic population through Biomedical Fermentation-A Holistic Approach. International Journal of Pharmaceutical and Chemical Sciences 2015;4(2):216-221.

40. Sreelal AM, Ganti YB, Saokar MR. Critical Analysis on Pharmaceutics of Alcoholic Preparations (Asava-Arishta) In Ayurveda. Journal of Ayurveda and Holistic Medicine 2013;1(9):15-23

41. Sheshadri C, Krishnan Nambisan PN. Standardization of asava/arishta: A Preliminary Study. Journal of Research in Indian Medicine 1976,11.4. 
42. Muzaffer A, Dasan KKS, Ramar C, Usman Ali S, Purushothaman KK. Experimental Studies on Fermentation in Asavas Part I Draksharishta. Ancient Science of Life 1982,148-152.

43. Muzaffer A, Dasan KKS, Ramar C, Usman Ali S, Purushothaman KK. Experimental Studies on Fermentation in Asavas Part II Draksharishta. Ancient Science of Life 1983,216-219.

44. Lal UR, Tripathi SM, Jachak SM, Bhutani KK, Singh IP. Chemical changes during fermentation of Abhayarishta and its standardization by HPLC-DAD. Nat Prod Commun 2010;5:575-9.

45. Wadher SJ, Puranik M, Yeole PG, Lokhande CS. Determination of ethanol in Abhayarishta by gas chromatodraphy. Indian J Pharm Sci 2007;69:152-4.

46. Kasture VS, Mutha SS, Gosavi SA, Bhalke RD, Pawar SS. Standardization of Abhyarishta as per WHO Guidelines. World J Pharm Pharm Sci 2013;3:510-8.

47. Shaila D, Santosh MK, Rao IS. Standardization of selected Asava and Aristas. Asian J Chem 2003;15:88490

48. Wadkar KA, Kondawar MS, Lokapure SG. Standardization of marketed Amritarishta- A herbal formulation. Int J Pharmacogn 2016; 3(9):392-9.

49. Singh IP, Lal UR, Tripathi SM, Jachak SM, Bhutani KK. HPLC Analysis and Standardization of Arjunarishta - An Ayurvedic Cardioprotective Formulation. Sci Pharm 2009;77:605-16

50. Singh H, Mishra SK, Pande DM. Standardization of Arjunarishta formulation by TLC method. Int J Pharm Sci Rev Res 2010;2:25-8

51. Ragini H, Amita P, Jain AK. An approach to standardize Arjunarishta: a well-known Ayurvedic formulation using UV and Colorimetric method. J Med Pharm Allied Sci 2012;1:77-84.

52. Tiwari P, Patel RK. Quantifi cation of gallic acid and ellagic acid in Arjunarishta by validated HPTLC Densitometry. Int J Pharm Sci Res 2012;3:2215-23.

53. Singh H, Parihar SS, Mishra SK, Rathore A. Standardization of Ashokarista formulation by TLC method. Int J Pharm Tech Res 2010;2:1427-30.

54. Kumar T, Larokar YK, Jain V. Standardization of different marketed brands of Ashokarishta: An Ayurvedic formulation. J Sci Inno Res 2013;2:993-8.

55. Govindarajan R, Singh DP, Rawat AKS. Validated RPLC Method for standardization of Ashokarishta: A polyherbal formulation. Chromatographia 2008;68:873-6.

56. Vador N, Vador B, Hole R. Simple spectrophotometric methods for standardizing Ayurvedic formulation. Indian J Pharm Sci 2012;74:161-3.

57. Bhondave PD, Devarshi PP, Mahadik KR, Harsulkar AM. 'Ashvagandharishta' prepared using yeast consortium from Woodfordia fruticosa fl owers exhibit hepato protective effect on $\mathrm{CCl} 4$ induced liver damage in Wistar rats. J Ethnopharmacol 2014;151:183-90.

58. Kushwaha R, Karanjekar S. Standardization of Ashwagandharishta formulation by TLC method. Int $\mathrm{J}$ ChemTech Res 2011;3:1033-6.

59. Rasheed A, Roja C, Reddy GAK, Reddy BS. Formulation, standardization and pharmacological evaluation of a poly herbal traditional remedy Ashwagandharishtam. Orient Pharm Exp Med 2012;12:51-8.

60. HPTLC profi ling, and biological evaluation of Asvagandhadyarista: A comparative study of three famous commercial brands. Anc Sci Life 2014;33:16571.

61. Sankar K, Bhutani KK. Standardization of a polyherbal Ayurvedic formulation: Ayaskrti. Indian $\mathrm{J}$ Tradit know 2011;10:589-93.

62. 'Sekar S, Vinothkanna A, Mariappan S. Tracking the organoleptic and biochemical changes in the Ayurvedic polyherbal and native fermented traditional medicines: Balarishta and Chandanasava. Int J Pharm Pharm Sci 2014;6:521-6.

63. Tatke P, Jirge S, Gabhe SY. Marker based standardisation of plant based formulations containing Brahmi using bacoside a by HPTLC. Int J Pharm Pharm Sci 2014;6:202-7.

64. Alam M, Rukmani B, Shanmughadasan KK, Purushothaman KK. Effect of time on the Fermentation and storage of Candanasava. Anc Sci Life 1984;4:51-5.

65. Sankar K, Singh A. Standardization of polyherbalayurvedic formulation: Chandanasava. Int $\mathbf{J}$ Res Ayu Pharm 2011;2:665-9

66. Alam M, Dasan KKS, Joy S, Purushothaman KK. Comparative and fermentation standardisation Studies on Dasamularishta. Anc Sci Life 1988;8:68-70

67. Tiwari P, Patel RK. Development and validation of HPTLC method for quantifi cation of quercetin and rutin in Draksharishta. Asian J Pharm Sci Res 2012;2:7-18.

68. Pillai D, Pandita N. Determination of Quality Standards for Draksharishta, a Polyherbal Ayurvedic Formulation. Indian J Pharm Sci 2016;78(1):129-35

69. Pillai D, Pandita N. Validated high performance thin layer chromatography method for the quantifi cation of bioactive marker compounds in Draksharishta, an Ayurvedic polyherbal formulation. Braz J Pharmacog 2016;26:558-63

70. Tiwari P, Sen DJ, Patel RK. Development and Validation of HPTLC Method for Quantifi cation of Gallic acid and Catechin from Draksharishta. Asian J Res Chem 2013;6(3):248-53.

71. Sailor G, Seth A, Parmar K, Patel M, Shrirang P. Standardization of marketed Drakshasava - A polyherbal Ayurvedic product. Int J Pharm Sci 2013;4:363-70.

72. Lal UR, Tripathi SM, Jachak SM, Bhutani KK, Singh IP. RP-HPLC analysis of Jirakadyarishta and chemical changes during fermentation. Nat Prod Commun 2010;5:1767-70.

73. Gharate MK, Pawar R, Kasture V, Patil R. Evaluation of quantitative parameters of Ayurvedic formulation: Kankasava. Int J Pharm Pharm Sci 2011;3:43-5.

74. Arora P, Ansari SH, Anjum V, Mathur R, Ahmad S. Investigation of anti-asthmatic potential of Kanakasava in ovalbumininduced bronchial asthma and airway infl ammation in rats. J Ethnopharmacol 2017;197:242-9

75. Sathyajith R, Krishnamurthy MS, Shimi Ben CJ, Trimurthy SK. Pharmaceutico-chemical analysis of kharjoorasava and evaluation of its clinical effi cacy in panduroga. Int J Res Aayu Pharm 2014;5:447-51.

76. Sanmuga PE, Priya ES. Determination of Ethanol Content in Ayurvedic Formulations Kumaryasava and Mustakarista by Gas Chromatography. Indian J Pharm Sci 2015;77:120-5.

77. Dash VB, Junius AM. A Handbook of Ayurveda. Kandern, Germany: Narayana Publishers 2003.

78. Tatke PA, Elamthuruthi AT, Shah CR, Khan TA, Gabhe SY. Standardization of marketed Kumariasava; An Ayurvedic Aloe vera product. J Pharm Biomed Anal 


\section{5;37:937-41.}

79. Garg S, Bhutani KK. Chromatographic analysis of Kutajarista-Anayurvedic polyherbal formulation. Phytochem Anal 2008;19:323-8.

80. Shouche YS, Kumar H, Pandey PK, Doiphode VV, Bhutani KK, Patole MS et al. Microbial community structure at different fermentation stages of Kutajarista, a herbal formulation. Indian J Microbiol 2013;53:11-7.

81. Hiremath SG, Joshi DD. Role of different containers and methods on alcoholic preparations with reference to Kutajarista. Anc Sci Life 1991;10:256-63.

82. Mansuri AA, Desai SS. Systemic standardization of Lohasava-An antianemic polyherbal formulation. Indian Drugs 2017;54(09):33-7.

83. Rasheed A, Sri MT, Mohammed-Haneefa KP, ArunKumar RP, Azeem AK. Formulation, standardization and pharmacological studies of Saraswataristam: a polyhedral preparation. Pak J Pharm Sci 2014;27:1163-9.

84. Bhujbal P, Sandhya P. Chromatographic analysis of bioactive markers in Vidangarista, an Ayurvedic polyherbal formulation. J Planar Chromatogr 2012;25:427. 